\title{
KİRA PARASI ARTIŞLARININ SINIRLANMASI
}

\author{
Yrd. Doç. Dr. Hüseyin ALTAŞ *
}

\section{§ 1- KIRA PARASININ TESPITI}

\section{A- Genel Olarak}

Kira sözleşmesi, tarafların özgür iradeleriyle kurdukları bir Borçlar Hukuku sözleşmesidir. Dolayıstyla, kira parasının tespitinde aslolan, tarafların özgür iradeleriyle belirledikleri bir bedel ve artırım oranıdır'. Ancak, kira sözleşmesi toplumun genelini ilgilendiren bir sözleşme olduğundan zaman zaman kira parasının tespiti ve artırım oranını hakkında kanun koyucunun ve yargının müdahaleleri görülebilmektedir².

\section{B- Kira Bedeli Artış Oranın Belirlenmesi}

Kira bedeli, sözleşmenin asıl unsurudur. Taraflar bir kira sözleşmesinde bedel üzerinde anlaşmamışlarsa, kira sözleşmesi kurulamaz ${ }^{3}$. Kira parası kira sözleşmesinin objektif esaslı noktasıdır ${ }^{4}$. Sözleşmenin esaslt noktalarında anlaşma yoksa sözleşmenin kurulduğundan söz edilemez.

Ülkemizdeki esas sorun, yüksek enflasyon nedeniyle tarafların özgür iradeleriyle belirledikleri kira bedelinin sonraki yrllardaki artısııın nasıl tespit edileceği konusudur.

* Ankara Üniversitesi Hukuk Fak. Medeni Hukuk Anabilim Dalı Ö̌retim Üyesi

1) Aral Fahrettin. Borçlar Hukuku Özel Borç İlişkileri, Ankara 1999, sh.217; Yavuz Cevdet. Türk Botçlar Hukuku Özel Hükímler, 5. Bası, Istanbul 1997 sh.245:Karahasan Mustafa Reşit, Türk Borçlar Hukuku, Özel Hükümler, Istanbu! 1992, sh.465 vd.; Y3.HD. Sinin 13.3. 1996 tarih, 716 esas, 3055 saytl karan(YKD.1996, sh.536)

2) Kirą parasının tespiti yöntemi kamu düzeniyle ilgilidir. Yavuz, sh.247 dip. Not. I ] de antan Yargitay kararları; Aral, sh.217 vd.

3) Aral, sh.216

4) Gauch Peter, Von den Wesentlichen Vertragspunkten, Recht 1991, sh.46:Guhl/Merz/Koller. Das Scweizeriche Obligationenrecht, Zürich 1991. sh.97:BGE 97 Il 55 


\section{I-Genel Olarak (31.12.1999 tarihine kadar)}

31. 12. 1999 iarihinden önce, ülkemizdeki son kira artış oranı Yargıtay kararları nedeniyle yıllık \% 65 olarak uygulanmaktaydı. Kira sözleşmesi, bir özel hukuk sözleşmesi olduğu halde, yukarıda da belirtildiği gibi zaman zaman kanun koyucu ve yargı tarafından, kira bedelinin artışı konusunda müdahaleler görülmüştür ${ }^{5}$. Ülkemizde. yıllardan beri kira bedelinin artı̧ oranı hususunda tarafların tam özgür oldukları söylenemez. Kira parasıyla ilgili 4531 saylı son kanunun mülkiyet hakkının özüne dokunduğu, dolayısıyla sözleşme özgürlüğüne bir sınırlama teşkil ettiği savunulursa, bu sinırlamanı, yıllardan beri zaten Yargıtay tarafından değişik oranlarda uygulanmakta olduğunu söylemek hiç de yanlış olmaz ${ }^{6}$.

Kanun Koyucu, Kira parası artış oranı hakkındaki tarış̧malara 453! sayılı kanunla iki yıllığına son noktayı koymuştur?. Bu Kanun'dan önce kira parası artış oranı Yargıtay içtihatlarıyla belirlenmekteydi. Yargıtay" in eski içtihatlarına göre, kira parası artış oranları, önce emsal kira esasına, sonra ekonomik esaslara, hak ve nesafet kurallarına uygun olarak belirleniyordu $^{8}$. 5.4.1994 tarihinde hükümetin açıkladığı ekonomik önlemler paketindeǹ sonra, ülkemizdeki aşırı enflasyon dar gelirlinin. yani zayıf olanların durumunu iyice güçleştirdi. Yargıtay 3. Hukuk Dairesi, bu durumda ekonomik yönden zayıf olan dar gelirlinin önemli

5) Leumann, Die Teilnichtigkeit privatrechtlicher Verträge nach art.20.Abs. OR.be! Übetsshrietung kriegwirt schaftjicher Höchtspreisvorschriften, SJZ.1943, sh.237: Geselz zur Regelung der Miethöhe, http://www gesetzeaktuelf.de/Gesetzestexte/mhg.htm, 01.03.2000: : Der Vergleihsmietenbegriff des Desetzes zur Regelung der Miethöhe. htt//www.wowi.de/info/gesetze/mietrecht kommentare/vergleichsmietenbegriff.htm, 04.03.2000; Y.3.HD.6.12.1994 tarih, E. 14420.1557। sayılı kararı(YKD.1995, sh.388); Y.3.HD.sinin 2.4.1996 tarih. 377 esas. 4339 sayılı kararı(YKD.1996, sh.1051)

6) Yavuz Nihat. Kira Parasının Saptanmasına İlişskin Yarogıtay Kararlarındakj Gelişmenin Sistematik Açıllanması, YD. 1988, sh.134-183,283-311.416-525: Y.3.HD.6.12.1994 tarih, E.14420, 15571 sayılı kararı(YKD.1995, sh.388): Y.3.HD.sinin 2.4.1996 tarih, 377 esas, 4339 sayılı kararı(YKD. 1996, sh.105i)

7) Cumburiyetin kuruluşundan sonra 1926 yürürlüğe giren Borçlar Kanununa göre. kira sözleşmesinin tarafları sözleşme özgürlüğünün genel sınırlama hükümleri saklı kalmak şartıyla, kira bedelinin artış miktarını özgür iradeleriyle tespit edebiliyorlardı. Ancak, 1940 yılında ikinci dünya savaşının da etkisiyle Milli Korunma kanunu kabul edildi. Bu kanunun 30. Maddesine göre, kira bedelinin 1939 yılı rayiçleriyle dondurulması zorunlułuğu getirildi. 1947 tarihinde bu hüküm kaldırılarak kira bedetji artış oranı serbest bırakıldı. Bu tarihten sonra Türkiyede ki nüfusun ve şehirleşmenin hızlanması nedeniyle kira sorunun ülke ekonomisinde ciddi sıkıntılar açacağı korkusuyla kira!arı 1953 rayiçiyle donduran ve kiralayanın fesih hakkın sınırlayan 6570 sayılı "Gayrimenkul Kiralan Hakındaki Kanun" yürürlüğe konuldu. Ancak, Anayasa Mahkemesi, 26.031963 tarih. 1963/3 esas, 1963/67 sayılı kararıla(RG.31.5.1963, sh.11416), bu kanunun kira bedelini sinırlayan 2.ve 3. Maddeleri mülkiyet hakkınıs özüne sınırlamalar getirdiği dolayısıyla Anayasaya aykırı olduǧu gerekçesiyle iptal etmiștir.

8) Detaylı bilgi için bkz. Yavuz, sh.244-245, Aral, sh.221: Karahasan, sh.465 vo. 
bir gider kalemi olan kira parası artışıla ile ilgili olarak 6.12.1994 tarihi bir kararla", enflasyonun y1llk \% 65 den fazla olmas1, halinde kira parasının bir yıllık zaman diliminde en fazla $\% 65$ oranında artırılabileceğine hükmettì. Bu kararın gerekçesinde, özellikle, taşınmaz mal sahiplerinin yüksek enflasyondan dar gelirliler kadar etkilenmediği hususuna yer verilmiştir. Çünkü, taşınmaz fiyatları bu dönemde aşırı artmış ve sabît gelirlilerden oluşan kiractların korunmaya muhtaç oldukları bir kez daha ortaya çıkmıştır. Aynı şekilde, kira paraş, taşınmaz mala yatırılan sermayenin ancak bir gelir bölümünü olușturur. Dolayısıyla, ekonomik, sosyal, siyasî ve idarî kararlarla durmadan ree] anlamda artan taşınmaz fiyatları da bir gelir sayılır. Yargıtay, bu kararının gerekçe bölümünde, Anayasa Mahkemesinin 1963 tarihinde, 6570 sayılı Gayrimenkul Kiraları Hakkındaki Kanun' un 2 ve 3.maddelerinin iptaliyle ilgili olarak da, amacı kiracıyı korumak olan bu Kanun' un, kira parasındaki "sınırlı artış ilkesini" kaldırdığının da kabul edilemeyeceği yolundaki görüşüne de değinmiştir. Nitekim Yargıtay da, 1964 tarihli içtihadıyla ${ }^{10}$, kira bedelinin "hak ve nesafete uygun" olarak sınırlı şekilde artırılabileceğini kabul etmiştir. Bu nedenle, Yargıtay, toptan fiyat endeksindeki artışı bir yıllık kira dọneminde \% 65 i geçtiği hallerde, bunun kira parasına yansıyan bölümünün \% 65 oranı ile sıntrlandırılmasını hakkaniyete uygun ve âdil bir ilke olduğu sonucuna varmıştır'.

Kısacası, 31.12.1999 tarihine kadar, ülkemizdeki taşınmaz mallartn kira paraları artış oranı Yargıtay kararları nedeniyle ${ }^{12}$ yıllık \% 65 olarak uygulanıyordu.

\section{II-4531 Sayıl Kanunla Gelen Değişiklikler Tarihinden Itibaren) \\ ${ }^{13}(01.01 .2000$}

4531 sayılı Kanun' la getirilen düzenlemeye göre, "Sözleşmelerde kararlaşıırılan kira paraları 2000 yılında yıllık \% 25, 2001 yılında ise yıllık \% 10 oranında artırılabilir. Ancak, taşınmazın bulunduğu bölgede

9) Y.3.HD.6.12.1994 tarih, E.14420, I5571 saytl kararı(YKD.1995, sh.388); Y 3.HD .sinin 2.4.1996 tarih, 377 esas, 4339 sayılı karanı(YKD.1996, sh.1051)

10) YHGK nun 18.11.1964 tarih, 2 esas. 4 sayılı kararı(Yargıtay İçtihadı Birleștitıme Kararları, Hukuk Böłümui, Ankara 1981, sh.275 vd.

11) Y.3.HD.6.12.1994 tarih, E.I4420, 1557। sayılı karan(YKD.1995, sh.388): Y.3.HD sinin 2.4.1996 tarih, 377 esas, 4339 saytl ı kararı(YKD. I996, sh. 1051)

12) Y.3.HD.6.12.1994 tarih, E.14420, 15571 saylı kararı(YKD.1995, sh.388): Y 3.HD sinin 2.4.1996 tarih, 377 esas, 4339 sayıl kararı(YKD.1996, sh .1051)

13) 16.2 .2000 tarihinde, Gayrimenkul Kiraları Hakkında Kanuna Bir Geçici Madde Eklenmesi Hakkında Kanun adıyla 453I sayılı bir kanun çıkarılmıştır. Kanun tçin bkz. Resmi Gazete, 18.02.2000, Sayı 23968 
rayiç kira parasıındaki artış bu oranların altında ise, bu oranlar uygulanmaz.

Kira parasının yabancı para veya kıymetli madene endeksli olarak belirlendiği sözleşmelerde ayrıca yıllık artış söz konusu değildir.

Kira parasının artış smırlarının aşılması amacıyla yeniden kira sözleşmesi yapılamaz.

Kira tespit davalarında da yukarıdaki sınırlamalara uyulur."

\section{1- Kira Parası Artış Oranına Getirilen Sınırlamalar}

Bu Kanun' la, 2000 yılı içinde yapılacak tüm kira artışları $\% 25$. 2001 dekiler ise, \% 10 ile sınırlandırılmıştır. Bu hüküm emredici nitelik taşıdığından, her ne kadar yayın tarihi 18.02.2000 olsa da, değişiklik metninde 2000 yılı esas alındığından, 01.01.2000 tarihinden itibaren yapılacak tüm kira parası artışları \% 25 ile sınırlandırılmıştır. Dolayısıyla, madde metni ile "yayınlanma tarihinden itibaren yürürlüğge girer" ibareleri çelişmektedir. Bu Kanun' un eleştirilerisi aşağıda ayrıca yapılacaktır. Bu bölümde kanunun nasıl uygulanması gerektiği üzerinde durulacaktrs.

6570 sayılı Gayrimenkul Kiraları Hakkındaki Kanun gereği, kiracı istemedikçe kiralayan onu ancak belirli nedenlerle(ihtiyaç, el değ ş̧tirme ve tadilat gibi) tahliye edebilir ${ }^{14} .6570$ sayll $_{1}$ Kanun' a göre, kira parası anlaşmazlığı nedeniyle kiracıyı kiralanan yerden tahliye etmek mümkün değildir. Başka bir deyişle, kiracı, kira arış oranlarına uyduğu ve kira bedelini ödediği sürece onu tahliye etmek oldukça zordur. Yeni çıkan 4531 sayılı Kanun' un uygulamasında çeşitli ihtimalleri değerlendirmek gerekir. Burada üzerinde durulacak ilk ihtimal olarak, belirli süreli ve bu süre içinde kira artış oranları tespit edilmiş sözleşmelerin durumu incelenmelidir. Bu Kanun' da belirli süreli ve kira artış oranları önceden belirlenmiş sözleşmelerin durumu açıklanmamıştır. Örneğin. 1999 yılında üç yıllığına yapılmış ve her yıl \% 60 kira artış oranı öngören bir sözleşmenin durumu ne olacaktır. Kanımızca, Kanun Koyucunun kira bedeline getirdiği 2000 yılı için yıllık $\% 25^{\prime}$ lik sınırlama hukuka ve Anayasaya aykırılığı tartışılsa bile, iptal edilmedikçe uygulamada kalacağından. eşitlik ilkesi gereği, süreli ve bu süre için kira parası artış oranları tespit edilmiş sözleşmelerde de, bu orana uyulması gerekir. Çünkü. Kanun Koyucunun bu şekilde bir düzenlemeyle kira parasına

14) Aral, sh. 284 vd.:Yavuz, sh. 325 vd. 
sınırlama getireceğini önceden bilmek ve öngörmek mïmkiin değildir. Eşitlik ilkesi gereği, süreli ve bu sürede kira parası artış orant öngören sözleşmenin yenj şartlara uydurulması icap eder. Aksi halde, kanunun amacından sapılmış ve eşitlik ilkesine ters davranılmış olur. Örneğin, 1999 yılında üç yıllığına yapılan ve yıllık \% 50 kira parası artış oranı öngören bir sözleşmede, kira parasının 2000 yilında $\% 25,2001$ yılında \% 10 artacağının kabul edilmesi lâzımdır.

Kira parası artışıyla ilgili olarak ele alınması gereken ikinci husus, bir yıllığına yapılan ve uygulamada genellikle bir yılın sonunda belirli bir oranda kira artışı öngörülerek devamı kiralayanın iradesine bırakılan sözleşmelerin durumudur. Bu tür bir sözleşmede de, eğer kira sözleşmesinden sonraki bir tarihte verilmiş tahliye taahhütnamesi veya belirli tahliye nedenleri yoksa, kira sözleşmesi yenilenerek devam edeceğinden, 2000 yılındaki kira artış oranı sözleşmede belirtilen değil. Kanun' da belirlenmiş olan \% 25 lik orana göre tespit edilir. Örneğin, bir kira sözleşmesinde, sözleşme süresi bir yll olarak ve taraflar isterlerse kira bedelini \% 65 artırımla yenileneceği öngörülmüş ise, bu sözleşmede de kira artış oranı 2000 yılı için yıllık \% 25 olacaktır.

Üçüncü ihtimal olarak, belirli süre için yapılan kira sözleşmesinin(örneğin ü̧̧̧ yıllığına) 2000 yılında süresinin bitmesi düşünülebilir. Bu tür bir sözleşmenin genel olarak birinci ve ikinci ihtimalden pek bir farkı yoktur. Burada da, eğer kira sözleşmesi yenilenmiş veya yenilenecek ise, kira parası artı̧̧ oranı 2000 yılı içinde kanun gereği yıllık \% 25 olacaktır.

Kısacası, 4531 sayılı Kanun gereği 2000 yılındaki tüm kira bedeli artış oranları kural olarak yıllık \% 25 ile sınırlıdır.

\section{2- Kira Parası Artış Oranına Getirilen İstisna}

Taşınmazın bulunduğu bölgedeki râyiç kira parasındaki artış, 2000 yılı içersinde \% 25 in altunda kalırsa, Kanun' daki oran değil bölgede oluşan râyiç kira bedeli ödenir. Bu ihtimalin iulkemizde gerçekleşme ihtimali oldukça zor olduğundan üzerinde durmak yersizdir.

\section{3- Kira Bedelinin Döviz Gibi Kıymetli Şeylerle Ödenmesi Hali}

4531 sayılı Kanun' un 1 maddesiyle getirilen geçici 7, maddenin 2. fıkrasına göre, "Kira parasının yabancı para ve kıymetli madene endeksli olarak belirlendiği sözleşmelerde ayrıca yıllık artı̧̧ uygulanmaz." Bu madde ile, daha önce yabancı para veya medeni eşyaya endeksli olarak 
yapılan kira sözleşmelerindeki artı̧̧ oranlarının iptali amaçlanmıştur. Bu Kanun yürürjükte olduğu sürece, kira bedeli yabancı para veya kjymetli madene endeksli sözleşmelerde, kira artış oranı sıfır olacaktır. Kanun Koyucu, burada dövizlerin değerinin ve yıllik enflasyonun \% 25 artacağı faraziyesinden hareketle, taşınmaz mal sahibinin kaybının olmayacağ ihtimaline yer verilmiştir. Kanun Koyucuya göre, ilk fıkradaki \% 25 lik artış ile yabancı para ve enflasyon artışı arasında bir dengenin olacağ varsayılmışıtır. Bu sınırlama ile ilģili eleştirilerimiz de aşağıdadır.

\section{4- Kira Artışıyla İlgili Sınırların Aşılması İçin Yeni Sözleşme Yapılamaz}

453 s sayılı Kanunun 1, maddesiyle getirilen geçici 7. maddenin 3. fikrasına göre. "Kira parasının artış sınırlarının aşılması amacıyla yeniden kira sözleşmesi yapılamaz." Kanun Koyucu, bu fıkra ile, birinci ve ikinci fıkradaki koyduğu kuralların kanuna karşı hile yoluyla aşılmasını yasaklamışıtr. Bu hüküm olmasaydı da, yine de, genel hükümlerden yolà çıkılarak(kanuna karşı hile), kira artış oranlarını bertaraf etmek için yeni sözleşme yapılamazdı. Uygulamada, gïçlü taşınmaz sahipleri, zayıl durumdaki kiracılarını baskıyla kira artış oranının \% 25 den tazla tutulduğ yeni bir kira sözleşmeși yapmaya zorlayabilir. Emredici kurallar karşısında, bunları ihlal eden bir sözleşme yapılırsa, bu sözleşme geçersiz olur. Başka bir deyişle, taraflar arasındaki ikinci kira sözleşmesi(kira artış oranının \% 25den fazla olmasını kamutle etmek için yapılan) geçersiz olur. Kiracı bu sözleşmeyi zorlamayla imzalasa bile iptali için dava açabilir. Böyle bir durumda, eski kira sözleşmesi. kira parasının 2000 yılı içinde $\% 25$ artırılmasıyla geçerlitiğini korumaya devam eder. Kanun Koyucu, bu kuralla, \% 25 esasının aşılmasında kullanılabilecek bir gediği(kanuna karşı hile) kapatmaya çalışmıştır. Ancak, eleştiriler bölümünde de değinileceği gibi, bu Kanun ‘ un getirdiği sınırlamalar uygulamada başka yollarla aşılabilir. Kanun Koyucunun kanuna karşı hile yolunu özel olarak kapatmasına gerek yoktur. Çünkü. kamuna karşı hile zaten hukuka aykırıdır ${ }^{1.5}$.

\section{5- Kira Tespit Davalarında da Bu Simırlamalara Uyulması}

Gayrimenkul Kiraları Hakkındaki Kanun' a eklenen 7. maddenin son fikrasına göre, "Kira tespit davalarında da yukarıdaki sınırlamalara uyulur." Buna göre, 2000 yılı içinde yürütülecek tüm kira tespit davalarında da kira parası artı̧ oranları $\% 25$ olacaktır. Bu hükümle. daha önce açılmış ve bu kanun yürürlükteyken açılacak kira bedeli tespit davalarında hâkimin işi oldukça kolaylaşmıştır. Mevcut kira parașna

15) Eren Fıkıet. Borçlar Hukuku Genel Hükümler, Istanbul I99k. sh.345 vol. 


\section{\$-2- 4531 Sayılı Kanunun Deǧerlendirilmesi}

18.05.1955 tarihli Gayrimenkul Kiraları Hakkındaki Kanunun' a Bir Geçici Madde Eklenmesi Hakkındaki 4531 sayılı Kanun' la getirilen deģişikliklerin ayrı ayrı ele alınıp değerlendirilmesi gerekir. Öncelikle, kira parası artışlarının 2000 yılı içinde yıllık \% 25 ile sınırlandırılmasının. sözleşme özgürliuğ̈i ve Anayasa' ya aykırılık yönünden değerlendirilmesi, aynı şekilde bu kuralın mülkiyet hakkının özüne dokunup dokunmadığının da tespiti icap eder.

\section{A- Kira Parası Artış Oranının Sınırlandırılması}

\section{I- Kira Parası Artış Oranının Sınurlanmassının Sözleşme Özgürlüğü Açısından Değerlendirilmesi}

\section{1- Genel Olarak}

Sözleşme özgürlüğü, kişilerin borç ilişkilerini düzenlerken, hukukun çizdiği yasal çerçeveye uygun olmak kaydıyla yapacakları sözleşmeleri doğrudan doğruya düzenleme yetkisine sahip olmalarıdır ${ }^{1 t}$. Sözleşme özgürlüğünün temelini irade özerkliği oluşturur. Bu nedenle, öncelikle irade özerkliğinin aydınlatılması gerekir.

\section{2- İade Özerkliği}

İrade özerkliği, liberal ve bireyci hukuk sistemlerinin temel kuraIıdır ${ }^{17}$. İrade özerkliłği sözleşme özgürlügüüün de temelindeki düşüncedir. Liberal ve bireyci görüşe göre, insanlar irade özerkliğine sahip olup, hukuki iliş̧ilerini istedikleri gibi düzenleyebilirler. Başka bir deyişle. irade özerkliği, kişilerin özel hukuk ilişkilerini kendi özgür iradelerine göre dïzenleyebilmeleridir ${ }^{18}$.

16) Krammer, Berner Kommentar, Band.VI., Teilband. Lieferung I. Obligationenrecht, Allgemeiner Bestim- mungen, Art.19-20 OR., Bern 1990. Nr.3637; Oftinger Karl, Die Vertragsfreiheit, in :"Die Freiheit des Bürgers im schweizerischen Recht", Festgabe der juristischen Fakültaten det schweizerischen Universitaten zur Hundertsjahrfreier der Bundesferfassung, Zürich 1948. sh.367: Eren, sh .278: Altaş, sh.43;Başpınar Veysel, Borç Sözleşmelerinin Kısmi Butlanı. Ankara 1988, sh.13 vd.

17) Oftinger, sh.52-53, Bucher Eugen, Schweizerisches Obligationenrecht, Allgemeiner Teil , 2.A., Bern 1988, sh.87, Eren,I. sh.275; Başpmar, sh.13 vd.

18) Oftinger. sh.52: Flume Werner, Allgemeiner Teil des Bürgerlichen Rechts. Band.II, Das Rechtsgeschaft, Berlin/Heidelberg/New York 1975,sh.I vd.; Oğuzman/Öz. Borçlar Hukuku Genel Hükümler. İstanbul 1995, sh. 18 vó. 
Özel hukukta, kişiler, özgür iradeleriyle kendi sorumluktkları içinde özel ilişkilerini bizzat dizenleyebilirler. Bu düzenlemenin en ônemli ară da sözleşmedir. İrade özerkliğini sağlamada kullanstan bir diğer arą̧ da teşebbüs özguirlüğïdür. Bir hukuk düzeninde teşebbüs: özgürliiğü ne ölçüde geniş uygulanırsa, o kadar irade ozerkliğ̣i sağlanabilir. Teşebbüs özgürlüğünün olduğu bir toplumda, geliş̧me. demokrasi ve huzur vardır ${ }^{19}$. Teşebbüs etme hakkına sahip fertlerin özgür iradeleriyle yaptıkları sözleşme, bunu yapanlarm menfaatlerine de uygundur. Hiç kimse kolaylıkla kendi menfaatine olmayan bir sözleşme yapmaz. Başka bir deyişle, sözleşmeye dayanan her şey aynı zamanda âdilditit

Netice itibarıyla, felsefî, ahlâki ve ekonomik temellere dayanan irade özerkliği ilkesi, kişilerin özel hukuk ilişkilerini kendi özgür iradeleriyle doğrudan doğruya düzenleyebilmeleri yetkisidir ${ }^{2-}$. Ancak. şurasını belirtmek gerekir ki, Türk-İsviçre Borçlar Kanunu ģibi modern hukuk dưzenleri mutlak mânada irade özerkliğini kabul etmemişlerdir. Modern bukuk düzenleri, her hak ve özgürlüğün olduğu gibi, irade özerkliği. yani sözleşme özgürlüğüunün de sınırlarının olduğunu kabul etmişlerdir. Bu düşïncenin temelinde yatan esas unsura göre, irade özerkliği bir kural olarak hukuk düzeni tarafından ferde devredilen yetkidir.

\section{3- Sözleşme Özgürlüğï}

\section{a- Genel Olarak}

Liberal ve serbest ekonomiye uygun hukuk düzenlerinin gelişimiyle, sözleşme özgürliuğüi ilkesi de geniş bir uygulama alanı bulmuştur. Ancak. İkinci Dünya Savaşı sırasında ve sonrasında sözleşme özgürlüğüune getirilen sunırlamalar artmıştır ${ }^{2}$.

19) Kars. Iiren.l, sh.276

20) Kars.Eren. I, sh.276; Irade özerkliği her hukuk dïzeninde dar veva genis olarak vardır. Irade özerkliğine geniş yer ayıan hukuk düzenleri sözleşme öygürlugẹünii do kabul êtmiş olan liberal ve bireyci hukuk düzenleridir. Otoriter hukuk dizenleri imel mülkiyet ve özel girişim hakların tanımadıkları için, bu tür hukuk dü\%enlerinke iratle orerkliği en dar anlamda kullanılmaktadır. Katş. Flume. sh.l vd.:Buclser. sh.s?

21) Ottinger, sh.47: Schneider/Bring. Vertragsfreiheit als Privatslechtsocoriti. Naters/Bring 1960. sh.29 vd.: Reizer Ludwig. Vertragsfreiheit. Heute, 17. 1958. sh.1 vi: Tekinay/Akman/Burcuoğlu/Altop. Borçlar Hukuku Gencl Huikumicr, istanbut 1993, sh.362 vd: Altas, sh.43

22) Wolf Ernst. Vertragsfreiheit-Eine Ilision? Fest Schrift für Max Keller zam 65.Gcturstag. Zürich 1989, sh.358 vd.: Leuman, sh.237 vi.: Eren, 1. sh.27k: Baspiuar, sh. 18 
Sözleşme özgürlüğüi ilkesi, Borçlar Kanunu' nda tanımlanmamıştır. Kısaca, sözleşme özgürlüğünü, "kanunen sınırlanmayan ve engellenmeyen hukukî inkânlar çerçevesinde kişilere borç sözleşmeleri yapma yetkisinin tanınmasıdır şeklinde tanımlamak mümkündüir ${ }^{1 .}$. Sözleşme özgürlüğüunden amaç, fertlerin, sözleşme yaparken, onun çeşidini, tipini, içeriğini, tarafını ve şeklini seçebilme: seçilen ve yapılan bu sözleşmeyi değiştirebilme, sona erdirebilme hak ve yetkisine sahip olmalarıdir ${ }^{24}$.

Türk-İsviçre hukuk düzenlerinde, irade özerkliği kuralına göre, herkes Borçlar Kanunu' nun 19 ve 20 maddelerindeki sınırlamalara uymak kayđıyla, dilediği sözleşmeyi yapmak özgürlüğüne sahiptir. Sözleşme yapma özgürlüğü 1982 Anayasa' sinnn 48. maddesinde teminat altına alınmıştır. Bu maddeye göre, "Herkes......sözleşme yapma hürriyetine sahiptir"25. İrade özerkliği ve buna bağlı olarak da sözleşme yapma özgürlüğï de mutlak mânada kullanılamaz. Bu özgürlüklerin de sınırlarının olması doğaldır ${ }^{26}$. Borçlar Kanun' unun 19 ve 20 . Maddeleri, sözleşme özgürlüğüne genel sınırlamalar getirmiştir. Sözleşme özgürllüğü bir ülkenin ekonomik sistemi hakkında da önemli bilgiler vermektedir. Sözleşme özgürlüğünün en geniş uygulandığı ekonomik sistemler, günümüzdeki liberal ekonomilerdir. Ancak, liberal ekonomi sistemlerinin uygulandığı hukuk düzenlerinde dahi sınırsız bir özgürlük yoktur. Başka bir deyişle, sözleşme özgürlügünün de bir sınır vardır ${ }^{27}$. Sözleşme özgürlüğğinuin sınırlarını kısaca fỉilî ve kanunî olmak üzere iki kısımda inceleyebiliriz. Sözleşme yapma özgürlüğünün kanunî sınırlarını, Medeni Kanun' un ve Borçlar Kanun' unun sözleşme yapma ehliyetsizlikleri(MK.9-16-47), sözleşmenin şekli(BK.11-16) ve sözleşmenin içeriği(BK.19-20, MK.23) şeklinde sıralayabiliriz ${ }^{28}$. Bunun yanında, sözleşme yapma özgürlüğüinün fiilî sınırlamaların ise, standart sözleşmeler, genel işlem şartları, formüler sözleşmeler. yığın

23) Wolf, sh.360, Altaş, sh.44, Başpınar, sh.16: Oğuzman/Öz, sh. 19;

24) Merz Hans. Vertrag und Vertragschluss, Freiburg 1992, Nr.83 vd.; Reizer, Vertragsfreiheit, JZ.1958, sh.1 vd.

25) Sỉzleșme yapma özgüirlüğü her ne kadar 1982 Anayasasında "Sosyal ve Ekonomik Haklar ve Ödevier" düzenlenmişse de 1961 tarihli Anayasanın 40. Maddesinde olduğu gibi, "temel haklar ve ödevler" bölümünde yer alması daha doğru olurdu. Altaş. sh.44; Başpınar, sh.12

26) Koller Alfret, Schweizerisches Obligationenrecht, Allgemeiner Teil, Band,I. Berlin 1996. Nr.816 vd.: J.eumann, sh.237 vd.;Altas, sh.45; Baspmar, sh.18

27) Y.3.HD.sinin 22.i.1996 tarih, E.1995/4823. 1996/3463 sayılı kurart, YKD.1996, Sa.5. sh $7 ! 0.712$

28) Wendrich Wolfgang, Disharmonie zwischen des Nichtigkeiten des Vertrags nach Artikel 20 OR und Artikel 26 des Bundesgesetz über den Erwetb von Grundstüchken durch Personen im Ausland, Zitrich 1990, sh.6 vd.: SchneiderBring. sh. 42 vd.; Başpmar. sh. 19 
yanında, sözleşme yapma özgürlügüünün fiilî sınırlamaların ise, standart sözleşmeler, genel işlem şartları, formüler sözleşmeler, yığın sözleşmeleri, pazar sinırlamaları ve kartel anlaşmaları şeklinde örnekleyebiliriz ${ }^{29}$.

Inceleme konumuz kira bedeli artış oranının kanunla tespitinin sözleşme özgürlüğünü ihlal edip etmediği olduğundan, sözleşme özgürliağuinüin kanunla nasıl ve ne zaman sınırlanabildiğini belirlemek gerekir.

\section{b- Sözleşme Özgürlïğünün Kanunla Sınırlanması}

Sözleşme özgürlüğünün günürnüzde, liberalizmin doğduğu XVII. ve XVIII yüzyıllardaki kadar geniş uygulama alanı bulduğu söylenemez. Sosyal eylimler(örneğin güçsüzlerin korunması), ferdin iradesinin toplumun genel iradesine ve menfaatine uygun olması gerektiğini savunmaktadır. Ekonomik yönden ilerlemiş toplumlarda sözleşme özgürlüğuinü geniş anlamda uygulamak mümkün olabilir. Ancak. Türkiye gibi gelişmekte olan ülkelerde sözleşme özgürlïğünün tam anlamıla uygulanmasını savunmak oldukça zordur. Özellikle İkinci Dünya Savaşı sırasında ve sonrasında, günümüzün ilerlemiş ve ekonomik yönden gelişmiş olarak nitelendirilen Avrupa ïlkelerinde bile sözleşme özgürlüğüne kanunla önemli ölçüde sınırlamalar getirilmiştir ${ }^{20}$. Elbette ideal olanı, serbest piyasa gereği sözleşme özgürlüğüne genel sınırlamalar dışında sınırlama konulmamasıdır. Ancak, bazı dönemlerde ülke ve kamunun genel menfaati için sözleşme özgürlüğüne geģici sïrelerle sinurlamalar getirilebilir. Bu sinırlamalar egemenlik hakkını millet adına kullanan meclis tarafından kanun yapma yoluyla olmalıdı. ${ }^{3 !}$. Örneğin, İsviçre' de 1939-1952 yılları arasında Federal Konsey, özellikle kira, elektrik, gaz ve gıda maddelerinin satış fiyatlarına( toptan ve perakende satışlarda) sınırlama getirmiştir ${ }^{32}$. Almanya' da halen yürürlükte olan ve kira artışlarını düzenleyen kanun vardır. 18.12.1974 tarihinde çıkarılan ve 97.1998 tarihinde değiştirilen ve halen Almanya da yürürlükte olan, "Kira Artışlarını Düzenleyen Kanun" da

Grundstüchken durch Personen im Ausland, Zuirich 1990, sh.6 vd.: SchneiderBring, sh. 42 vd.; Başpinar, sh. 19

29) Wendrich, sh.6 vo. Schneider-Bring, sh.42 vd.

30) Leumann. 237-242; Eren. I, sh.278; Başpmar, sh.18

31) Leumann. sh.237; Gesetz zur Regelung der Miethöhe. http:/www gesetzeaktucll.de/Gesetzestexte/mhg.htm, 01.03.2000; Der Vergleihsmietenbegriff des Desetzes zur Regelung der Miethöhe, htt://www, wowi.del info/ gesctze/mietrecht kommentare/vergle!chsmietenbegriff htm, 04.03.2000

32) Leumani. sh. $237 \mathrm{vd}$. 
incelenmelidir ${ }^{33}$. Almanya da, kira artışları halen de sınırlı olarak uygulanmaktadır ${ }^{34}$. Bu ülkede kira artışları kiralanan yerin metre karesine göre belirlenmektedir.

Ülkemizde, enflasyon ile topyekûn bir mücadelenin başladığ1 dönemde, kanunla bazı eşyaların ve hizmet bedellerinin sınırlandırılması. sözleşme özgürlüğünü ihlâl etse de, kabul edilebilir. Çünkü, sözleşme özgürlüğünün mutlak mânada uygulandığı hiçbir hukuk düzeni yoktur. Hukukun asıl amacı, sosyal adalet ve eşitliği sağlamak, kamu düzenini muhafaza etmektir. Özellikle, sosyal hukuk devletinde, güçsïzlerin korunması ilkesi kabul edilmiştir. Sosyal amaçların gerçekleşmesi için, bazı dönemlerde, istisnaî bir zaman süreci içersinde, devletin ekonomiye mücadelesi yadırganmamalıdır.

Hukuken doğru ve ideal olanı, kira bedelinin serbest piyasada kendiliğinde, arz ve talep dengesine göre oluşmasıdır. Ancak, Türkiye'nin geleceği ve ekonominin rayına oturması için, herkes gibi, mülk sahipleri de fedakârlık yapmak zorundadırlar. Nasıl ki, sâbit gelirli fertlere sadece belirli rakamlarla đicret artışı veriliyorsa, kira bedelindeki artıs oranının da sadece geçici bir dönem için sınırlanması mülkiyet hakkının özüne dokunmadığı gibi, sözleşme özgürlüğüne aykırı değildir. Burada çatışan menfaatler söz konusudur. Ferdin(taşınmaz sahibi) menfaati ile toplumun menfaati çatışmaktadır. Hukukun menfaati bu dengeyi sağlamaktır. Dolayısıyla, sözleşme özgürlüğ̈i ilkesiyle toplumun genel menfaati çatıştığında, Kanun Koyucu tarafından, her özgürlükte olduğu gibi, sözleşme özgürlüğüne de makul ve kabul edilebilir geçici sınırlamalar konulabilir. Kira bedelindeki artış oranlarının kanun koyucu tarafından smırlandırılması sözleşme özgürlüğ̈üne aykırı olsa da, geçici bir dönem için kabul edilebilir. İsviçre' de bile, 1939 yılında bizimkine benzer bir şekilde, kira bedellerindeki artış oranları sınırlanmıştı ${ }^{35}$.

Kanımızca, kira parası artış oranı kamu menfaati gereği kanunla sınırlanabilir. Bu sınırlama, "sınırlı artı̧̧ ilkesi" ve "geçici süre olma" özelliği taşımalıdır. Çıkarılan 4531 sayılı Kanun' da, "sınırlı artı̧ ilkesi" ve geçici süre olma özelliği taşıdığı için, sözleşme özgürlüğü kurahını ihlâl etmez. Çünkü, kira sö̌lleşmeși her ne kadar bir özel hukuk

33) Gesetz zur Regelung der Miethöhe, http//www.gesetzeakturell.de/Gesetzestexte/mhg.htm, 01.03.2000

34) In welcher Höhe kann die Miete gemindert werden?. http:www.jurathek,de/kassing/miete/minderung/minhoeh.htm.; Welche vertraglichc Regelungen stehen in ihrem Mietvertrag?, htp://www.juratek det kassing/miete/minderung/minvertrhtm: Wanngeht dem Mietherdas Recht auf $\mathrm{M}$ i e $\mathrm{tm}$ i n d e r u g g e r lore $\mathrm{g}$ ? http://www juratek.de/kassing/miete/minderung/reverlus.htm.; 06.03.2000

35) Leumann, sh.237 vd 
sözleşmesi olsa da, ottada kamu menfaatini ilgilendiren bir durum vardır:, zayıf tarafm korunması, toplumda huzur ve güvenin sağlanması için bazen sözleşmelere müdahale gerekebilir ${ }^{36}$. Nitekim, Hukuk düzenleri benzer olan İsviçre ${ }^{37}$. Almanya ${ }^{38}$ ve Türkiye' de ${ }^{39}$, zaman zaman Kanun Koyucu kira bedeline müdahale etmiştir. Yargıtay da son olarak çıkartlan 4531 sayılı Kanundan önce, kira bedeli arış oranınında "sınırlı artış oranını" uygulamıştır. Anayasa Mahkemesi" nin 1963 tarihinde 6570 sayll Kanun" un 2 ve 3. maddelerini iptal etmesinin nedeni, bu Kanun hükümlerinin "sınırlı artı̧ ilkesini" değil, "kira bedelini dondurma" prensibini benimsemiş olmalarından kaynaklanmıştır. Yani, yeni Kanun' la kira bedeline ilişkin olarak, 1963 tarihli Anayasa Mahkemesinin iptal kararındaki durumdan farklı bir düzenleme getirilmiştir. Başka bir deyişle, Anayasa Mahkemesinin iptal ettiği 6570 sayılı Kanun un 2 ve 3 . maddelerinde kira bedelinin dondurulma ilkesi varken. 4531 sayılı Kanunda kira bedelinde "sınırlı artış ilkesi" benimsenmiştir. Yargıtay 4531 sayılı Kanun' dan önce, kira parası artış oranını sınırlı artı̧ ilkesine göre(\% 65) çözmekteydi. Buna göre, 4531 sayılı Kanun daki kira bedeli artı̧̧ oranının 2000 yılı için $\% 25$ ile sinurlandırılması, sözleşme özgürliigüüne aykırı ise, Yargıtay" in yıllardır uyguladığı \% 65 oranındaki artıs esası da, sözleşme özgürlüğüne aykı'ıdır. Kanımızca, ülke gerçekleri nedeniyle, ne yeni yasadaki $\% 25$ lik ne de Yargıtayın yıllardır uyguladığı $\% 65$ lik artış kira parası arış oranı sözleşme özgürlüğüne aykırı değildis ${ }^{40}$. Bu Kanun' un çıkarılış amacı enflasyon ile mücadeledir. Devletin 2000 yılı için öngördiiğij enflasyon oranı yıllık \%25 dir. Burada şu sorunun tartışıllması gerekir. Enflasyonun nedeni kira artışları mıdır, yoksa, enflasyon arttığı için mi. kira paraları artmaktadır? Kira parası artışı sınırlamasıyla ilgili olarak savunduğumuz görüşün temelinde hedeflenen enflasyon rakamlarmun gerçekleşmesi yatmaktadır. Eğer "ülkemizdeki enflasyon 2000 yılı için yıllık \%25 den fazla olursa, kira parası artışına getirilen smırlama da sözleşme özgürłïğ ïne aykırı hale gelecektir. Bu sınırlama oranł(\%25)

36) Yavuz, sh.247 dip.11:Kira parasının tespiti yöntemi kamu düzeniỵle ilg̣ilidis.

37) Leumanı. sh. $2.37 \mathrm{vd}$

Geset\% zur Regelung der Miethöhe. http:/wwwigeselzeaktutell de/Gesetzestexte/mhg.htm. (11.03.2000; Der Vergleihsmietenbegriff des Desctzes zur Regelung der Miethöhe, htt//www.wowi de/info/gesetze/mietrecht komnetutarc/vergleichsmietenbegriff .htm, 04.03.2000

39) 453 I saylı yasa, 18.02 .2000 tarihli RG.Sa.23968

40) Ancak, 15.12.1999 tarihli ve 4489 saylı "Kanunni Faiz ve Temerrüt Faizine İliskin Kånunda Deģişiklik Yapılması Hakkında Kanun" a göre, temerrüt faizleri Merkęz Bankası Reoskont oranıyla tespit edilecektir. Bu oran 2000 yılı için yaklaşı \% 65 dir. Temerruit faizini yüksek tutup, enflasyon nedeniyle kira atrtişın! \% 25 lo sinulamak celişki teşkil eder. Bura göre, devletin kendi alacaklaunda uyguladı aylık \% 6 lak faiz oranı da fahiştir. Bu nedenle, hem temerrüt faizinin hem de kamus allaciklatı için uygulanan fajz oranlarının da kira artış orenında olduğu gibi \% 25 c çekilmesi gerekir. Yabancı patalardaki artış sınırlaması, dar ve sabit gelirliye yapılan ücret zamları da, faiz yasalarının tekrar gözden geçirilmesi zorunlulığunı doğurmuştur. 
enflasyon oranının altında kalırsa, sınırlama mülkiyet hakkının özüne dokunmuş ve sözleşme özgürlïğ̈üne aykırılık teşkil etmiş olduğundan Arayasa Mahkemesince iptal edilebilir.

\section{B- Kira Bedeline Getirilen Sınırlama Mülkiyet Hakkının Özünü Zedelemez}

Medeni Kanun' da ve Anayasa' da "mülkiyet" kavramı tanımlanmamıştır. Ancak, Medeni Kanuı' un 618. Maddesinde, mülkiyetin unsurları sayılmıştır. Bu maddeye göre, "Bir şeye mâlik olan kimse, o şeyde kanun dairesinde dilediği gibi tasarruf etmek hakkını haizdir: haksız yere o şeye vaz'iyed eden her hangi bir kimseye karşı istihkak davası ikame ve her nevi müdahaleyi men edebilir." Mülkiyet. kısaca, "eşya üzerinde en geniş yetki sağlayan aynî haktır" şeklinde tanımlanabilir". Anayasa' nın 36 ve 13. Maddelerinde. mülkiyet hakkı teminat altına alınıştır. Medeni Kanun, mülkiyet hakkında, her hakta olduğu gibi, mutlak tasarruf ilkesinden ayrılarak, hukukun çizdiği sınırlar içinde maldan yararlanılabileceğini kabul etmiştir. Bu sınırlı tasarruf hakkına göre, mâlik, malın fiilen kullantıması, semerelerinin toplanması, değişiklik yapılması, başkasına devredilmesi ve üzerinde başkası lehine bedelli yada bedelsiz hak tahsis edilmesi gibi yetkilere sahiptir. Bu nedenle, malik taşınmazını kural olarak dilediği kişiye dilediği bedelle kiraya verebilir ${ }^{+2}$. Ancak, Kanun Koyucunun Medeni Kanun' un 618 . maddesi uyarınca, mâlikin bazı haklarını kısıtlama yetkisinin olduğunu kabul etmek gerekir. Çünkü, madde metninde mülkiyet hakkmın kanun dairesinde kullanılacağına işaret edilmektedir. Kanun Koyucu da, Medeni Kanunun 618. maddesindeki hakkını kullanarak, kira bedeli artış oranını 2000 yılı için yıllık \% 25 ile sınırlamıştır. Mülkiyet hakkının kanunla geçici sürelerde kamu menfaati gereği sinırlandırılması onun özünü tahrip etmez. Anayasa' nın 35. maddesine göre, mülkiyet hakknna ancak kamu yararı amacıyla ve kanunla sınırlama konulabilir. Anayasa' nın 13. maddesinde ise, "kanun kamu yaranı amacıyla da olsa bir hakkm özüne dokunamaz" denmiştir.

Taşınmaz malların konut ve iş yeri olarak toplum için büyük önemi vardır. Ülkemizde olduğu gibi, konut darlığı olan ülkelerde, devletçe gerekli tedbirler ahınmadığı sürece, kiralar olağan dışı yükselebilir. Bı durum, özellikle ekonomik yönden zayıf, dar ve sınırlı gelir sahipleri açısından zorluklar getirerek, toplumda huzursuzluk yaratabilir. Konun Koyucu' nun toplumu bundan korumak amaciyla, mülkiyet hakkınm özüne dokunmamak şartıyla, kira konusunu düzenlemesi ve bu alanda bir

$41)$ Oğuzman/Seliçi Eşya Hukuku, İstanbul 1997, sh.255 vd.

42) Aral. sh.217:Yavis, sh .245: Karahasan, sh.465 vd. 
takım sınırlamalar getirmesi kamu yararının bir gereğidir ${ }^{43}$ Ekonomik kuralların dünyadaki gelişmiş ülkelerdeki gibi ülkemizde de sağlam bir şekilde oluşması ve uygulanması için alınmış kira parası aıtışıın sınırlanınası kuralı, 2000 yılında işçi memur ve emeklilere yapılacak zam oranıyla da aynı olduğundan, bu kuralın mülkiyet hakkının özünü zedelediğinden bahsedilemez ${ }^{44}$. Anayasa Mahkemesi 1963 tarihinde kira paralarının dondurulmasıyla ilgili 6570 sayılı Kanun' un 2 ve 3 . maddelerini iptal etmiştir. Ancak, bugünkü koşullar ve 4531 sayılı Kanun la getirilen kira parası sınırlamalarına iliş̧in kurallar 6570 sayılı Kanunla öngörülen kira parasınun dondurulması kuralından oldukça farklıdır. 4531 sayılı Kanunla da kira parasının dondurulmásı öngörülseydi, tabii ki mülkiyet hakkının özü zedelenmiş ve bu kural Anayasa ihlal edilmiş olurdu. Kira parasının kanunla sınırlanmış olması mülkiyet hakkının özünì zedelemez. Çünkü, kira parası taşınmazdan elde edilen gelirin sadece bir kalemini oluşturur. Özellikle, 2000 yılının ilk guinlerinde. ülkemizdeki taşınmaz mal fiyatları olağan dışı artımıştır. Bu artışlar da taşmmaz maldan elde edilen gelir grubuna girer ${ }^{+5}$. Medeni Kanuı Anayasa ve serbest ekonomi piyasası kurallarına göre. kira parası artış oranının kanunla sınırlanması kanımızca mümkündür. Kanıın Koyucu da 4531 sayı Kanunla bu mümkün olanı kamu menfatati gereğ yapmışıtr. Her hak ve özgürliikte olduğu gibi, mülkiyet hakkı ve sözleşme özgürlüğgünün de sınırlarının olması doğaldır ${ }^{\text {to }}$. Ancak. ülkemizdeki 2000 yılı enflasyonunun yıllık \% 25 üzerinde olması halinde toplumun her kesiminde olacağı gibi, taşınmaz malını kiraya verenlerin de mağdur olacağı, dolayısıyla onların mülkiyet haklarının özünün zedeleneceği ortadadır.

\section{C-Kira Parasının Yabancı Parayla Ödenmesi Haline Getirilen Sınırlama Doğru Değildir}

Ülkemizde kira paralarınır yabancı para veya kıymetli madene endeksłli olarak kararlaştırılmasına engel teşkil eden bir hukuk kuralı yoktur. Bu nedenle. kira sözleşmesinde taraflar, sözleşme özgürlüğỉ

43) Yavuz. sh.245: Anayasa Mahkemesinin 26.3 .1963 tarih, 1963/3 csas. 1963/67 salyol killilli(RG..31.5.1963. Sa.11416)

44) Ancak, millet vekillerinın kendilerine yaptıkları maaş zamımıla ilģili çıkartıkları yasamı bu ekonomik veri ve tedbirler içinde anlamak mümkün de ğildir. Kıyak cmeklilık olarak bilinen bu yasanın meclisten hızla çıkarılması. enflatsyonla mücardelede toplumun ve iş çevrelerinin samimiyeti yanında millet vekillerinin samimi olmadıklanının bir göstergesi olarak üzücüdür.

45) Aral, sh.225, dip.not 37 de anılan Yargitay kararı

46) Koller. Nr.816; Bucher Eugen. Füt Mehr Aktionen denken. ACP.1986. sh. 24: Altaş..sh 45 
gereği de. kira bedelinin yabancı para veya kıymetli madene endeksli olarak ödenmesini kararlaştırabilirler ${ }^{47}$.

4531 sayılı Kanun' a göre, kira parasının yabancı para veya kıymetli madene endeksli olduğu durumlar da yıllık kira parası artışı uygulanmaz. Bu kural serbest piyasa ekonomisi ve sözleşme özgürlügüne aykırıdır. Çünkü, taraflar kita bedelini yabancı parayla tespit ettikleri durumlarda. yabancı paranın da bir yıl içinde değer kaybedebileceği gözden kaçulımamalıdır. Örneğin, 1999 yılında Amerikan doları enflasyon karşısında değerini korurken, Alman markı \% 20 lere varan değer kaybına uğramıştır. Bu nedenle, kira parasının yabancı para veya kıymetli madene endeksli olarak belirlendiği durumlarda, en azından yabancı paranın yıllık değer kaybı oranında kira parasının artırılabilmesi gerekir. Zira, öyle yabancı para veya kıymetli maden olabilir ki, 2000 yılı içinde olağan dışı değer kaybedebilir. Yabancı para veya kıymetli madeni eşyanın değeri 2000 yılı içinde $\% 25$ den az artarsa taşınmazını bunlar üzerinden kiraya veren ev sahibinin hakk1 zedelenmiş olur. Bu nedenle, "kira paralarının yabancı parayla ödendiği durumlarda artış olmaz" kuralı konulurken, yabancı para veya madeni eşyanın değer kayıp ve kazançları da göz önünde tutulmalıydı. Çünkü, bu tür yatırım araçlărının değerini Türkiye'nin belirlemesi mümkün değildir..Bunların değerini globalleşen diinyadaki ekonomik şartlar belirlemektedir. Dolayısıyla, kira parasının yabancı para veya kıymetli madene endekslendiği durumlarda, yıllık kira artışının uygulanmayacağını öngören hükmün, hukuken ve ekonomik olarak doğru olmadığı, bu kuralın mülkiyet sahiplerini mağdur edebileceği kanaatindeyiz ${ }^{48}$.

\section{D- Yeni Sözleşme Yapma Yasağının Gereksiz Oluşu}

Kanun Koyucu, 4531 sayılı Kanunla kira parast artış sınırlarının aşılması için yeni sözleşme yapılmasını yasaklamışır. Kanun Koyucu, bu kuralla, kira parası arış sınırlarının kanuna karşı hile yoluyla aşılamaz olduğunu ifade etmektedir. Bu yasak konmasa dahi, genel kural, kanuna karşı hilenin yasak olduğudur ${ }^{49}$. Başka bir deģişle, kanunun yasakladığı bir hususu aşmak amacryla, başka bir kanunu kullanmak hukuken yasaktır. Yeni Kanun' la getirilen, "kira parası sınırlamasının aşılması amacıyla yeni sözleşme yapılamaz" kuralı olmasa dahi, kira parası artış

47) AraI, sh.229, dip.not.39 da anılan Yargıtay Karar!

48) Bu tür yatırım araçlarına, Örneğin Amerikan doları ve Alman markına yıllık ne kadar faizin uygulanacağına Türkiye'den karar verilemez. Bu ülkelerdeki ve đünyadaki diğer ekonomik gelişmelere göre dolara ve marka uygulanan yıllık faiz belli olur.

49) Eren, sh.346 vd. 
sınıtlamasın aşmak amacıyla yapılan yeni sözleşmeler geçersizdir ". Dolayısiyla, bu kural, sadece genel bir kuralın teyidi anlamına gelir. Uygulamada, kiracilardan gabinle. ileri tarihli bir tahliye aahhïdij veya kiymetli evrak(bono gibi) alınmaktadır. Bu durumda, kiracı isterse. kira artıs sınırlamasını ihlal eden yeni sözleşmeyi, ileri tarihli tahliye taahhïdünü ve kiralayana verdiği kıymetli evrakın iptalini talep edebilir. Bunlar genel kurallar çerçevesinde çözülebilen durumlardır. Ancak, 453! sayılı Kanun, bunlardan kira parası sınırlamasının aşılması amacıyla yapılan yeni kira sözleşmesinin geçersiz olduğunu açıça düzenienmesinin anlamı, genel kuralın teyididir. Böyle bir durumla karşlaşan hakimin yapacağ 1 şey. yeni sözleşmenin iptaline ve kira sözleşmesinin eski halindeki kira bedelinin, 2000 yılı için yıllık \% 25 arturilmasina karar vermek olmalıdır.

\section{E- Kira Tespit Davalarında Sınırlama Konulması Hukuken Yanlıştır}

Kira tespit davass, kira parasının belirlendiğ davadır ${ }^{51}$. Kira sözleşmesinin tarafları. sözleşme özgürlüğü çerçevesinde, sözleşme süresi hoyunca ödenecek kira parasını serbestçe belirleyebilirler ${ }^{52}$. Şayet taraflar. kira sözleşmesi süresince uygulanacak kira parası artı̧̧ oranını tespit etmemişlerse, ilk yıllarda Kanun veya Yargıtay ca belirlenen aruș oranları uygulanır. Ancak, kira sözleşmesinin üzerinden uzunca yıllar geçınişse, bu kira artış oranları âdil olmayan sonuçlar doğurabilir. Bu âdil olmayan sonuçların engellenmesi için. kira tespit davası her zaman açılabilmektedir ${ }^{5.3}$. Cünkü, kira sözleşmesinden sonra uzunca bir zaman geçmişse. özcllikle enflasyon yaşanan ülkelerde para değeri olağan dışi azalmaktadır. Bu durumda, taraflar hâkimden, kira sözleşmeșinin yeni şartlara uydurulmasını da talep edebilirler. Hâkim, kira parasını objektif dïrüstlük(Medeni Kanın 2.maddesi) ve hakkaniyet kurallanı(Medeni Kanun 4. maddesi) içinde, sözleşmeyi yeni şartlara uyarlayarak, tespit eder $^{3+}$.

Kira bedeli tespit ve uyarlama davasında 2000 yılı içinde yıllık \% 25 lik bir sınırlamanın getirilmesi ilk bakışta âdil ve eşitlik ilkesine uygun gibi görünse de, eleştirilere açık bir kuraldır. Çünkiu. yıllar önce yapı lmış bir kira sözteşmesinde kira bedeli tespit davası açıldığında. \% 2.5 lik bir

50) Eren, sh. 346 vd.

51) Aral. sh.229 vd.:Yavuz, sh.245 vd,

52) Aral, sh.217: Yavuz, sh.245:Karalousan sh .465 vd.: Y3.HD, simn 13.3. 1996 taril. 716 osas. 3055 sáyll kararı(YKD. 1996. sh.536)

53) Aral, sh. 239

54) Aral, sh.230 vol. 
artış oranının uygulanması adalete aykırı sonuçlar doğurabilits.5. Aynı şekilde, bir yıl önce yarı bağış amacıyla ucuza kiraya verilmiş bir sözleşmede de kira parasının yeni yıl için tespiti nedeniyle açılan bir davada sınırlamanın uygulanması âdil olmayabilir. Başka bir deyiş̧le, çeşitli nedenlerle(zaman veya bağış gibi), râyiçinin çok altında kira bedeli olan taşınmazların kira bedellerinin yeniden tespitini içeren davalarda hâkimi \% 25 oranıyla bağlamak, hem yargı bağımsızlığını ihlâl eder hem de hâkime olan güvenin sarsılması anlamına gelir. Bu durumdaki, taşınmaz malını kiraya vermiş olan maliklerin hakları da zedelenmiş olur. Kira parası artı̧̧ına getirilen sınırların kira tespit davalarında da kural olarak uygulanması yasanın bütünlügù ve eşitlik açısından doğrudur. Ancak, bu kuralı hiç istisnası olmayan emredici bir hüküm şekline getirmek yanlıştır. Bu kural olmasaydı, uygulamađa hâkim kira tespit davaları yoluyla 4531 sayılı Kanunla gelen bazı olumsuzlukları giderme imkanına sahip olurdu. Ne yazık ki, Kanun Koyucu uygulamada kira tespit davalarında da \% 25 lik sınırı koymakla hukuka aykırı biçimde hâkimin elinden takdir hakkını almıştır. Çünkü, kira tespit ve uyarlama davalarında, hakim, objektif dürüstlük ve hakkaniyet kuralları ile adâletin săglanması için, takdir hakkına her zaman sahip olmalıdır ${ }^{56}$.

\section{BIBBLIYYOGRAFYA}

Altaş Hüseyin: Şekle Aykurahğgn Olumsuz Sonuçlarının Düzeltilmesi, Ankara 1998

Aral Fahrettin: Burçlar Hukuku Özel Borç Iliş̧kileri. Ankara 1999

Başpınar Veysel: Borç Sözleşmelerinin Kısmi Butlanı. Ankara 1998

Bucher Eugen: Für mehr Aktionendenken ACP..1986

Bucher Eugen: Schweizerischen Obligationenrecht Allgemeniner Teil 2. Auflage. Zürich 1988

Eren Fikret: Borçlar Hukuku Genel Hükümler. İstanbul 1998

Flume Werner: Allgemeiner Teil des Bürgerlichenrecht. 2.Band, Das Rechtsgesclaft Hiedelberg-New York 1992

Gauch Peter: Von den Wesentlichen Vertragspunkten, Recht 199I

Gufhl/Merz/Koiler: Das Schweizerische Obligationenrecht, Zirich 1991

55) Karş. Aral, sh.23C vd.

56) Aral, sh.229 
Gürsoy/Eı̀n/Cansel: Eşya Hukuku Ankara 1984

Kalahisan Mustafa Reşit: Türk Borçlat Hukuku Özel Hükümler, İstanbul 199?

Karmmer Ernst: Berner Kommentar. Band.VI., I Tcilband. Licferung I. Oblygationenrecht. Allgemeiner Bestin- mungen. Ait.19-20 OR.. Bern 1940

Koller Alfret: Schweizerisches Obligationenrecht, Allgemeiner Teil. Berlin 1996

Leumann Peter: Dic Teilnichtigkeit privatrechtlicher Vartrege nach art.20.Abs. OR.bei Ubersshrietung kriegwirt schaftlicher Höchtspreisvorschriften. SJZ.1943

Merz Hans: Vertrag und Vertragschluss, Freibug 1992

Oftinger Karl: Die Vertragstreiheit, in :"Die Freiheit des Bürgers Im schweizerischen Recht", Festgabe der juristischen Fakültaten der schwerycrischen Universitalco zur Hundertsjahrfieier der Bundesferfassung. Zürich 1948

Og̣uman/Öz: Borçlar Hukuku Geriel Hükümler. İstanbul 1995

Oğuman/Seliçi: Eşya Hukuku. Isstanbul 1997

Rerzit 1.udwig: Vertragsfreiheit, Heute. JZ, 1958

Schneider/Bring: Vertragsfreiheit als Privatsrechtsbegriff . Naters/Brı! 1960

Tekinay/Akman/Burcuoğlu/Altop: Borçlar Hukuku Genel Hükimicr. istantul 1993

Wendnch Wolfgang: Disharmonie zwischen des Nichtigkeiten des Vertags nach Artikel 20 OR und Artikel 26 des Bundesgesetz über den Erwerb von Grundstüchken Jurch Personen im Ausland, Zürich 1990

Wolf Ernst: Vertragstreiheit- Eine lilısion? Fest Schrift für Max Keller zum 65. Geburstag. Zürich 1989

Yavuz Ccydet: Türk Borçlar Hukuku Özel Hükümler, İstanbul 1997

Yavıız Nihat: Kira Parasının Saptanmasına İlişkin Yargstay Kararındaki Gelişmenin Sistematık Açıkłanması,Yargıtay Dergisı̇ 1988

\section{ÖZET}

Kira parası artış oranları toplumda her zaman güncel ve tartışmalı bir konu olmaştur. Çünkü, kira sözleşmesi, toplumun büyük çoğunluğunu ilgilendiren, kamu düzeniyle ilgili olma özelliğine sahip bir özel hukuk 
sözleşmesidir. Kira parası artı̧̧ oranlarının tam serbest bırakılması ekonomik yönden zayıf olanların durumunu oldukça güçleştirmiş ve toplumda huzuru bozmuştur. Bu nedenle zaman zaman Kanun Koyucu veya Yargı organları kira parası artış oranlarına müdahale etmiştir. Son olarak, 16.02.2000 tarih ve 4531 sall yasayla Kanun Koyucu kira parası artış oranlarını 2000 yılı içinde yıllık \% 25, 2001 yılı için yıllık \% 10 ile sınırlandırmıştır. Kanun Koyucu bu yasayla, yabancı para veya kıymetli madene endeksli kira parası artış oranını da sıfır olarak kabul etmiştit. Söz konusu sınırlamaların aşılması için yeni sözleşme yapılması da bu yasayla yasaklanmıştır. Aynı şekilde, kira tespit davalarında da bu stnırlamalara uyulma zorunluluğu getirilmiştir.

Kanun Koyucunun kira parasıyla ilgili olarak getirmiş olduğu bu sınırlamalar toplumda özellikle de hukukçular arasında yoğun tartışmalara yol açmıştır. Bazı hukukçular bu sınırlamaların sözleşme özgürlügünï ihlal ettiğini, dolayıstyla mülkiyet hakkının özünü zedelediğini savunmaktadırlar. Ancak, kanımızca, İsviçre ve Almanya gibi hukuk dïzenlerimizin benzer oldugu ülkelerde yllardan beri uygulanmakta olan kira parası artış sınırlamalarının ülkemizde de uygulanmasında hukuki bir sakınca yoktur. Her hak ve özgürlükte olduğu gibi, sözleşme özgürlüğüinün de sınırlamalarının olması doğaldır. Bu nedenle kira parsı belirleme özgürlüğünün kamu menfaati nedeniyle sınırlanması mümkündür. Ancak, bu sınırlamaların 4531 sayılı yasada olduğu gibi "sınırlı artı̧ ilkesi" ne uygun ve geçici süreyle sınırlı olmas; gerekir. Mülkiyet hakkına, kamu menfaati nedeniyle ve kanunla bazı sinırlamaların getirilmesini Anayasa da kabul ettiğinden, bu sınırlamaların mülkiyet hakkının özünü de sınırlamadığı ortadadır.

\section{SUMMARY}

Rental increase rates have always been a fresh and ever discussed subject in the society. The main reason ist that, the lease contract is a private law contract, which the Majority of the Society is interested in and which is related with the public order. When the rental increase rates have been let completely free, this situation have put the people wiht Law income in a bad position and some problems have been orisen in the society. For that reason from time to time both the Law-maker and the judiciary orgens gave decisions priorly abaut the rental increase rates . Lastly, by an Act dated 16.02.2000 and nummered 4531 the Law-maker has limited the rental increase rates for the year 2000 with $25 \%$ and for the year 2001 with $10 \%$. By this Act the Law-maker has accepted the rental increase rate null for the lease contracts over foreign money and preciaus stones. It is also forbidden to enact new contracts in order to 
escape from these limitations Similarly, in the actions of determination of the rent, it is a recessity to follow these limitations

These limitations introduced by the Law-maker abaut the rents have caused enourmaus discussions in the society. especially amang the lawyers. Some lawyers claim that, these limitations are ageinst the contraciual freedam, there fore they give harm to the ownership right. But according tous, there is no reason. why these limitations abaut the rental increase rates shouldn't be applied in our cauntry, as they have been applied in Switzerland and Germany, which have a similer lawsystem to our Cauntry, for long years. Limitations in Contracttual freedam is natural, as it is in every right and freedam. So it should be possible to limit the fredem of decision in rental rates, because of the public welfare. But these limitations should be suitable to the "limited increase principle" and only for limited perionds, as they are regulated by the new Act no. 4531. As the Constitutions also accepts some limitations to the right of ownership, for publie welfare; these limitations do not harm the right of ownership. 